\title{
UNIATE SACRAL ARCHITECTURE IN THE GRAND DUCHY OF LITHUANIA: A SYNTHESIS OF CONFESSIONAL ARCHITECTURE
}

\begin{abstract}
Summary. The architectural legacy of the Unitarians in the former Grand Duchy of Lithuania has received little attention from researchers to this day. This article presents an architectural synthesis of the Uniate and Order of Basilians that reflected the old succession of Orthodox architectural heritage, but at the same time was increasingly influenced by the architectural traditions formed in Catholic churches. This article presents the tendencies of the development of Uniate architecture, paying attention to the brick and wooden sacral buildings belonging to the Uniate and Order of Basilians in the territory of the Grand Duchy of Lithuania. The early Uniate sacral examples reflected the still striking features of the synthesis, which were particularly marked in the formation of the Greek cross plan and apses in the different axes of the building. All this marked the architectural influences of Ukraine, Moldova and other areas of Central and South-Eastern Europe, which were also clearly visible in Orthodox architecture. Wooden Uniate architecture, as in the case of masonry buildings, had distinctly inherited features of Orthodox architecture, and in the late period, as early as the $18^{\text {th }}$ century, there was a tendency to adopt the principles of Catholic church architecture, which resulted in complete convergence of most Uniate buildings with examples of Catholic church buildings. Vilnius Baroque School, formed in the late Baroque era, formed general tendencies in the construction of Uniate and Catholic sacral buildings, among which the clearer divisions of the larger structural and artistic principles are no longer noticeable in the second half of $18^{\text {th }}$ century. The article also presents the image of baroque St. Nicholas Church, the only Uniate parish church in Vilnius city, which was lost after the reconstruction in the second half of the $19^{\text {th }}$ century.
\end{abstract}

Keywords: Uniate church, Uniates, visual reconstruction, Catholic church, Orthodox church, Basilian monasteries.

After the Union of Brest in 1596, a newly formed Uniate organisation was able to continue the doctrine of liturgy formed by the Orthodox church, largely in obedience to the Pope of Rome. From an architectural point of view, the house of prayer taken over from the Orthodox corresponded to the features of the architectural synthesis of various levels already formed by the Orthodox of the Grand Duchy of Lithuania. The concept of the Uniate ecclesiastical organisation in the Polish-Lithuanian Commonwealth was not only influenced by a Catholic ecclesiastical policy, but it also had taken over the artistic, structural models adopted in Catholic churches. With the formation of the Uniate church, the adoption of architectural tendencies prevalent in Western and Central Europe had been taking place since the establishment of the organisation and was especially strong in the $18^{\text {th }}$ century. ${ }^{1}$ The prayers of the Rosary or the feasts of the body of Christ were introduced into the life of the Uniate benches, bells and sometimes the pipe organs appeared in the churches, as well as the royal gates, which were no longer used in the installation of iconostasis. In addition, Latin or Polish languages were introduced in the daily life of the organisation. ${ }^{2}$ The conversion of the Uniates to Catholicism was a fairly common phenomenon due to the relatively low prestige and income of the Catholic church. Among the Uniates the number of nobles and townspeople consistently decreased. The Ruthenian Faith in the $18^{\text {th }}$ century started to be evaluated as the confessional relict of peasants. The cultural and financial predominance of the Catholic church was particularly pronounced in the border areas of Catholic and Unitate settlements. ${ }^{3}$ Nevertheless, at the junction of $17^{\text {th }}$ and $18^{\text {th }}$ centuries there was a clear preponderance of the 
number of Uniate parishes over Catholic parishes in the Polish-Lithuanian Commonwealth. ${ }^{4}$ The number of Basilian monasteries in 1772 in the territory of the Polish-Lithuanian Commonwealth was 147 men's and 25 women's monasteries, of which 62 men's monasteries existed in the St. Trinity and St. Nicholas provinces operating in Grand Duchy of Lithuania. ${ }^{5}$ After the approval of the Statute of the Order of Basilian in $1617^{6}$, its development was strongly influenced by the Jesuit order. Looking at the structural model of the order, artistic concepts, the model of dressing and the general construction of monastery buildings and especially brick churches were also adopted.

The main object of research of this work is the development tendencies of Uniate architecture, which were characterised by a combination of synthesis between Orthodox and Catholic architecture. In this work attention is paid to the brick and wooden sacral buildings belonging to the Uniate and Basilian orders in the territory of the Grand Duchy of Lithuania. The aim of this article is to analyse the development of volumetric-spatial compositions of Uniate sacral architecture and the influence of other denominations on the development of Uniate sacral architecture objects. Tasks of this article are to determine the structural features of the sacral buildings built by the first Uniates and Basilians; to present volumetric - spatial structural changes of wooden and brick architecture in the period of $18^{\text {th }}$ century.

So far there is no wide scope material covering the entire organisation of the Uniates and the development of their architecture. There has been a gradual increase in the focus on the legacy of Uniate architecture, but it is mostly limited to the study of individual objects. In general, the high concentration of existing objects and the small amount of available data have not received wider attention from researchers in this field so far. The lack of historiography and a common research base also caused the problem of assigning objects to a confessional organisation. For a long time, the building of Kruonis Orthodox Church was assigned to Basilians, but only recently after more detailed research it was established that this church belonged to an Orthodox monastery. ${ }^{7}$ In Lithuania during the last decade more attention has been paid to St. Trintiy Church. ${ }^{8}$ Rasa Butvilaite paid more attention to the gates of the Vilnius Basilian Monastery. ${ }^{9}$ A broader overview of Unitarian architecture objects is presented by Rūta Ostrovskaja. ${ }^{10}$ Grzegorz Ryżewski examined the Krasnybór Church in the territory of Poland in more detail. ${ }^{11}$ Data on other sacral objects have been published in fragments. Most of the data on the architecture of these buildings are presented in general publications, which also present the iconographic material of the destroyed churches. ${ }^{12}$ In Belarus these objects were studied in more detail by Tamara Garbus, ${ }^{13}$ Inessa Sliunkova, ${ }^{14}$ Irina Ozheshkovskaya. ${ }^{15}$ In Belarus detailed visual reconstructions of destroyed buildings are being prepared by the architect Aleksandr Nevar. ${ }^{16}$

In the preparation of this work a particularly important source about the development of St. Nicholas church is plans of this church discovered in the manuscript section of the Vilnius University Library, created before the reconstruction of the building in the second half of the $19^{\text {th }}$ century. ${ }^{17}$ Cartographic data allowed to determine the location of the former Merkine Orthodox, later Uniate church, and these plans are stored in the Lithuanian State Historical Archive (LVIA). ${ }^{18}$ Data about this church were discovered in Merkine magistrate's book of the first half of the $18^{\text {th }}$ century, ${ }^{19}$ and the Merkine eldership inventory of $1695-1697 .^{20}$

In preparing this article, a descriptive method as well as historical method for distinguishing the properties and development of objects were used. The method of stylistic analysis allows to distinguish changes in buildings and construction stages. Analysis of scientific literature and sources, field research and photo-fixation of the church of Krasnybór were carried out. In the case of the Church of St. Nicholas, a reconstructive method is used, which allows to restore the image of object's Baroque period. The latter methods allow to look at the initial condition of the reconstructed buildings and the structural and architectural image of the building during the Uniate management period. This is especially significant for objects which were reconstructed into Orthodox churches during the occupation of Tsarist Russia. 
THE FIRST BUILDINGS OF THE UNIATES AND BASILIAN ORDER IN THE TERRITORY OF THE GRAND DUCHY OF LITHUANIA

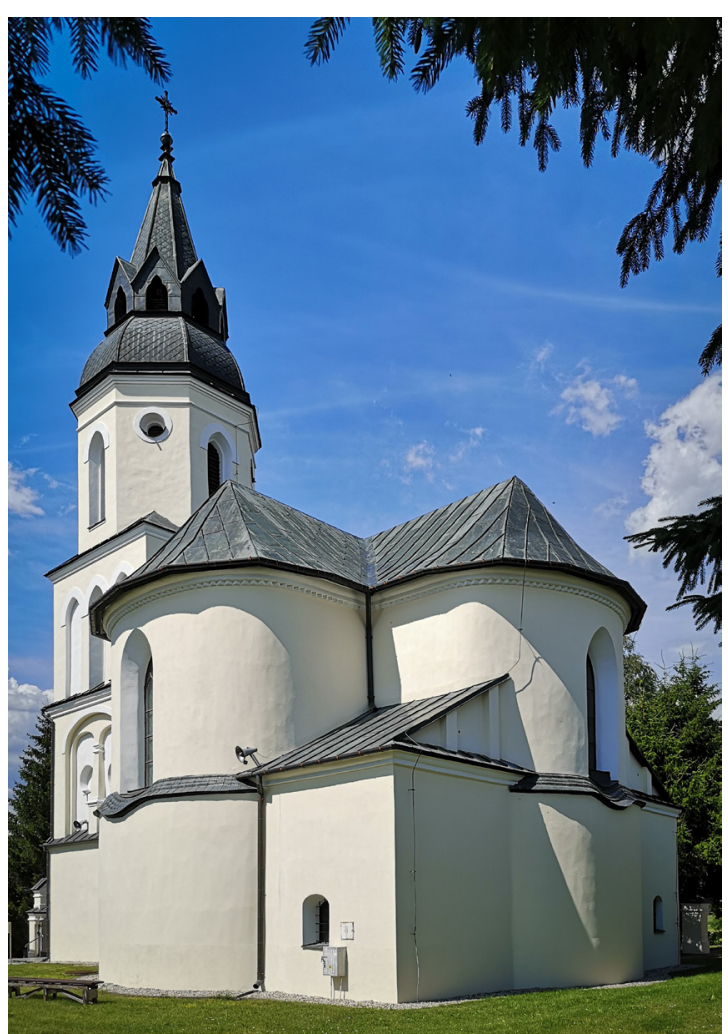

Fig. 1 Krasnybór Church, a former Basilian monastery's church. Photo by Žygimantas Buržinskas

Looking at the initial phase of the development of the sacred buildings managed by the Uniates, the liturgical principles of the Uniate construction corresponded to the features of the construction of the Orthodox houses of worship. Architectural changes of the buildings were primarily determined by the renovation of the old Orthodox churches, about the image of which in the $17^{\text {th }}$ century there are no sufficient data. The construction of new brick churches was mostly reflected in the activities and development of the Basilian Order, which were mainly marked by the construction of the late Baroque period. It is worth noting that the Orthodox architecture of $15^{\text {th }}-17^{\text {th }}$ centuries in the lands of the Grand Duchy of Lithuania was also touched by the Western architectural model, which is already clearly visible in the Gothic Orthodox churches of the first half of the $16^{\text {th }}$ century. This trend in Orthodox architecture also continued later, so when Uniates took after the Orthodox churches, they largely continued the tendencies of architecture prevalent in Western and Central Europe on which the Catholic Church had a great influence. The first brick buildings built for the Uniates reflect the structures of the Greek cross and rectangular plan. This shows a certain continuation of the early Orthodox traditions, but in other cases the architecture of the buildings did not differ from the Catholic churches in the territory of the Grand Duchy of Lithuania from the very beginning.

One of the earliest houses of prayer belonging to and built by the Basilians and their organisation in the territory of the former Grand Duchy of Lithuania are in the settlement of Krasnybór, ${ }^{21}$ which today functions as a Catholic parish church. Unlike in the case of Kruonis, ${ }^{22}$ a surviving document dated 1627 confirms that the building was built directly for the Basilian Order. The construction of the Orthodox church was financed by Adam Iwanowicz Chreptowicz, the chamberlain of Novogrudok (Naugardukas). The construction of the brick church was confirmed in letter of Samuel Litawor Chreptowicz, 1661, which stated that the "brick" building was built by his grandfather. ${ }^{23}$ The Basilians did not stay in Krasnybór for long, their monastery existed here only until the plague of 1627; later the Bernardines and Dominicans settled here. ${ }^{24}$ The structure of the building corresponds to the plan of the Greek cross, but there is also a tower with Renaissance and Gothic

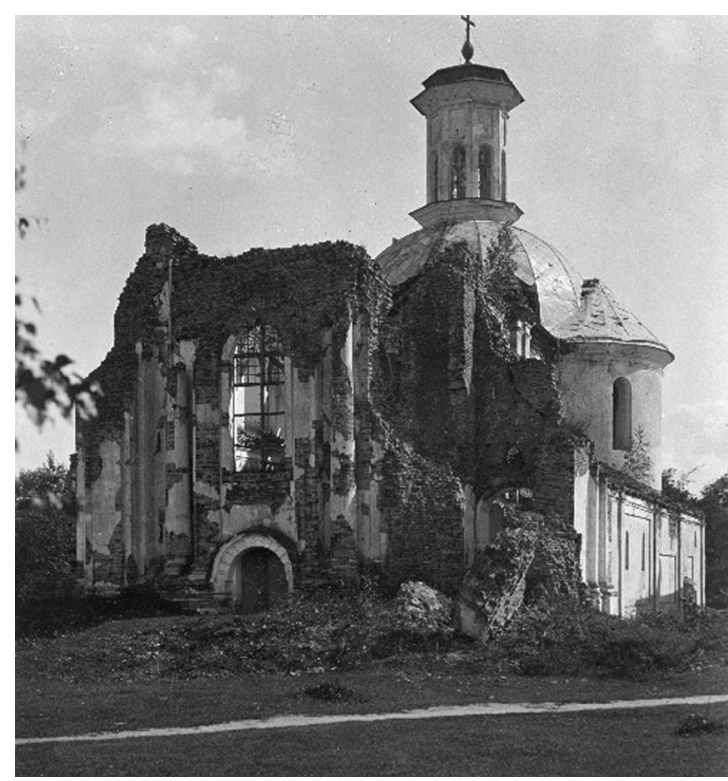

Fig. 2. The remains of the church of Byten Basilian Monastery. The photo shows a side apse of the church. IS PAN 0000017297 
elements near the front part. The structure of the building is original not only among the brick Uniate shrines remaining in the Grand Duchy of Lithuania, but also among the Orthodox churches built in the territory of the Grand Duchy of Lithuania at that time. Three axes of the cross-plan of former Orthodox church are completed by semi-circular apse. The formation of different axes of the cross-plan with semi-circular apse is not widely observed in the Northern and North-eastern Ruthenian lands. ${ }^{25}$ Such apse formation became more widespread in the Grand Duchy of Moscow only in the second half of the $17^{\text {th }}$ century with the spread of Baroque architecture. ${ }^{26}$ The structure of the building seems to be reflected in the construction of such wooden type Orthodox churches widespread in the eastern lands of the Grand Duchy of Lithuania and Ukraine in the $17^{\text {th }}$ century. ${ }^{27}$ The use of semi-circular apses is observed in the region of Bavaria and Austria. It is noteworthy that around the time when the Krasnybór Church was being built, the city cathedral in Salzburg was newly rebuilt, adapting the old foundations of the cathedral to the new Baroque structure of the building. The original examples of Greek cross dome plan of the $6^{\text {th }}-7^{\text {th }}$ centuries in the Caucasus region cannot be ruled out, among them the examples of the formation of semi-circular apses in the structure of this type of building can be found..$^{28}$ This principle of such Orthodox church construction has always been known among Orthodox people in Central and part of South-eastern Europe. ${ }^{29}$ It is also worth noting that such an accent of apse construction is also observed in other former Uniate churches not only in the territory of the Grand Duchy of Lithuania, but also in the Kingdom of Poland. ${ }^{30}$ The abundance of this type of Orthodox church in the current territory of Ukraine may indicate the genesis of the architectural idea of the Krasnybór church related to this region. Many churches of this type were built by adapting the building for defence. Examples of Orthodox churches similar to the Krasnybór plan can be found in the Moldovia region of Romania, where such structural planning in the $15^{\text {th }}-16^{\text {th }}$ centuries had become possibly the most traditional feature. Unlike in the case of Krasnybór, in this region the emphasis was on the plan of

- the Latin cross intertwined with Gothic architecture
(Orthodox churches of Neamt, Moldovita, Probota, Petrauti, St. John's Monastery, Voronet, etc.). Not only Renaissance but also Gothic accents appear in the former Basilian church of Krasnybór, which are reflected in the windows of the tapered arches installed in the apses. Despite the fact that the building was built on the basis of a Greek cross plan, the side apses did not have entrances, which are often seen in Orthodox architecture. In this case, the application of such a plan seems to have been reformulated from the solutions of the Latin cross churches, when structurally such a space reflects the standard transept installed in the churches. The building does not have any more pronounced allusion to the traditional Orthodox architecture due to the fact that there is no dome above the central part of the building. The tower of the building is structurally similar to other towers of the house of worship built in Renaissance architecture at that time.

Former Basilian Byten church of the original cross dome plan had essential similarities with the church of Krasnybór, its three lateral axes were complete by semi-circular apses, like those in Krasnybór. The general structure of the monastery in the first half of $17^{\text {th }}$ century is not known, but the monastery could have had fortifications in the middle of the $17^{\text {th }}$ century. ${ }^{31}$ In 1673 the fact of the construction of a new large church is mentioned, but it is not known whether the building was expanded or the structure of the cross-domed church was formed at that time. In 1775 , after the monastery was taken over by the Catholics, ${ }^{32}$ the architecture of the building could have changed significantly with the extension of the building and the formation of a Latin cross plan with two towers. The building could have undergone extensive reconstruction works in the second half of the $18^{\text {th }}$ century. This can be noted from the elements of the influence of the late Baroque and Classicism, which are seen in the former façades of the building. During the reconstruction, the building could have also been transformed into a basilica structure. A dome of regular circular plan rose above the building, and the truncated cone-shaped roofs were installed above the apses, connected with the domed roof structure. An octagonal lamp was mounted above the dome. Looking at the historical 
photographs, it can be seen that the old structure of the building had smaller windows than the window niches of later construction. Long, sufficiently narrow windows with semi-circular arches are visible in the apses.

Monolithic rectangular plan buildings were also typical of the first examples of Uniate sacral architecture. This is reflected in the remains of the buildings of houses of worship, which became known as the Belaya Tserkov near the Chereya manor. ${ }^{33}$ The nobleman of the Grand Duchy of Lithuania, Lew Sapieha, founded the Orthodox monastery in 1597 or 1598, but already in 1601 the monastery went to the Uniates. ${ }^{34}$ The $17^{\text {th }}$ century brick building corresponded to the feature of Renaissance architecture, which was common among other sacral buildings of the Grand Duchy of Lithuania. There is no complete consensus in historiography about the construction period of the building. ${ }^{35}$ The fact of the construction of a brick Orthodox church before the monastery fell to the Uniates would indicate a great rate of construction of the building, which is not typical for other brick buildings of the Grand Duchy of Lithuania at that time. During the subsequent reconstructions of the building, the building could take on Baroque forms. Such features are marked by the elements of the three-stage square-plan tower and the pediment of curved, broken forms that can be seen behind the tower in historical photographs.
The space of the building until the reconstruction in the $19^{\text {th }}$ century formed a rectangular single-nave plan completed by a semi-circular apse. The sacristies of a rectangular plan were placed on either side of the apse. During the reconstruction in the $19^{\text {th }}$ century, the side entrances and the installation of a massive dome above the central part of the building changed the structural view of the building.

There is a small brick house of worship named after St. Archangel Michael next to the Belaya Tserkov in the town of Chereya, the date of construction of which dates back to the $17^{\text {th }}$ century. This building was built on the site of another Orthodox monastery in Chereya, which had been operating in the area since the middle of the $15^{\text {th }}$ century. ${ }^{36}$ There are no exact data on when the church went to the Uniates, but it could have happened around the time when the nearby Belaya Tserkov monastery went to the Uniates as well. The early appearance of the small brick building severely damaged by later construction has changed considerably, so far it has retained a monolithic rectangular plan with a triangular apse, the width of which coincides with the width of the building itself.

\section{FEATURES OF WOODEN ARCHITECTURE}

One of the breaking points in the convergence of Uniate and Catholic churches is considered to be

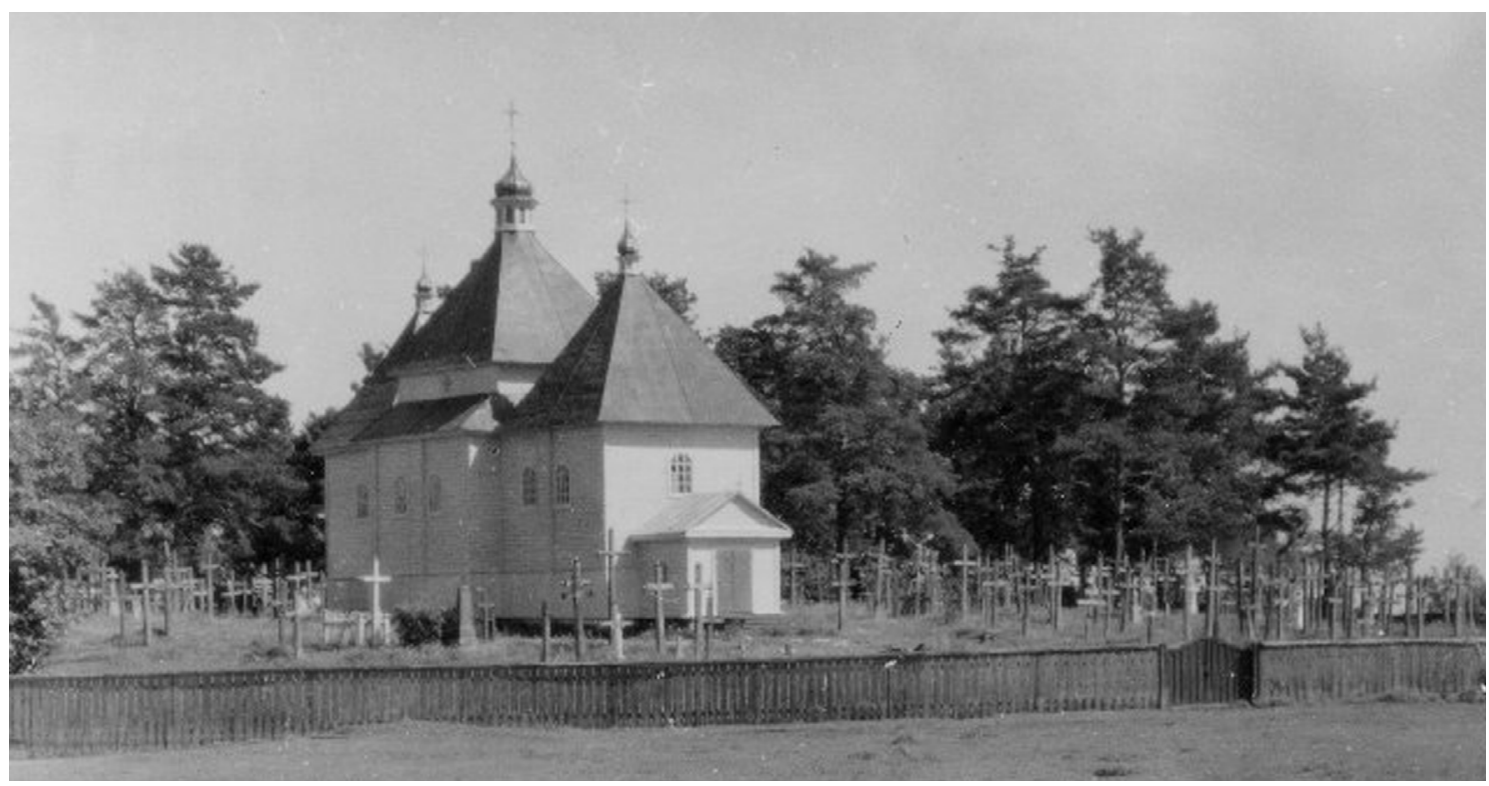

Fig. 3. Orthodox church of David Gorodok before the World War II. Photo by Stanisław Bochnig. IS PAN R0000026401 
the Zamość Synod of 1720. Nevertheless, before this event, not only the liturgical changes of the Uniate Church but also the architectural convergence of the Catholic and Uniate architectural conceptions also developed. Throughout the life of the Uniate organisation, the main network of parish churches consisted of wooden buildings, the original architecture of which is not widely known. In the current territory of Lithuania, only the old Orthodox houses of worship came into the ownership of the Uniates. In settlements other than Vilnius, the only more pronounced appearance of the Order of Basilians was in the village of Padubysis. ${ }^{37}$ There are almost no data about the network of Uniate parish Orthodox churches in present-day Lithuania. The only known wooden ${ }^{38}$ Uniate parish church of the first half of $17^{\text {th }}-19^{\text {th }}$ centuries existed near Merkine, in the Kalubiškès Folwark. ${ }^{39}$ There is only a small amount of information about the architecture of this building. The visitation documents of 1697 mention an already completely abandoned and collapsed building. The document states that the windows of the building were broken and had only one shutter; the floor of the building was broken inside. A choir to which there were no longer stairs is mentioned. ${ }^{40}$ It is worth noting that the church was equipped with two crypts for the founders of the Orthodox Church - members of the Kirdej family - so the question of the construction and date of the Orthodox church itself is questionable. It is probable that the church was still built under Orthodox dependence. The entire liturgical inventory of the building is indicated as early as the $17^{\text {th }}$ century, so the Orthodox church could have still been used. It is also important that local Uniates were buried near the building. ${ }^{41}$ No further information on the building is provided. It is known that the Uniate church in Merkine was restored in the $18^{\text {th }}$ century. The only clearer information about the structure of the building can be found in the land plan of the Merkine government manor of first half of the $19^{\text {th }}$ century, which depicts a rectangular plan church building. ${ }^{42}$

The notable prevalence of other wooden parish Unitarian Orthodox churches that have survived to this day is in the present-day territory of Belarus. The vast majority of churches were built in the $18^{\text {th }}$ century, and most wooden churches were built in rural areas. Features of the structure of these churches in comparison with buildings of the first half of the $18^{\text {th }}$ century and the end of the $18^{\text {th }}$ century had fundamental differences. Part of the churches built in the first half of the $18^{\text {th }}$ century reflect the features of the early Orthodox churches, which may have been taken over from Orthodox architecture. A prime example of this is the Orthodox church of David Garadok, which is structurally divided into three parts. Each part of the Orthodox church is covered by four-sloped pyramidal roofs, and at the top there are small domes with crosses. The church of Oltush has a similar structure, the detached part of which is decorated with domes of several parts of bright baroque forms. Churches of such features were also built in the $17^{\text {th }}$ and the first half of the $18^{\text {th }}$ centuries, in the current territories of Poland and Ukraine. Examples of a four-sloped three-part church roof may have been more widespread in the construction of Uniate churches in the first half of the $18^{\text {th }}$ century, but the construction works carried out in the second half of the $18^{\text {th }}$ century changed the features of construction of Uniate churches. The vast majority of churches built in the later period became visually close to the architecture of Catholic churches. The Uniate churches were built on the basis of traditional features of Catholic churches, forming a rectangular hall space and apse. In addition to these features, examples of two-tower system buildings appeared in the front of the churches (Dzivino). ${ }^{43}$ Examples of the structure of the plan of curved forms in the façade appeared under Baroque influence (Chotislav's church). ${ }^{44}$ It is also worth noting that some of the wooden churches were built on the basis of the basilica structure (Opal's church). ${ }^{45}$ St. Trinity church, near Shklov, on the other side of the Dnieper, had original forms, but its construction date is unknown. The apse of the building was formed not in a hemispherical shape but close to a regular circular plan with a separate conical roof. Using a similar principle, the former brick Pinsk Jesuit church was built at the end of the $18^{\text {th }}$ century. ${ }^{46}$ Such an example marks the feature of Uniate churches in using the semi-circular apses and to interpret them in their own way. 


\section{TRENDS IN LATE BAROQUE ARCHITECTURE}

Looking at the context of Basilian monasteries, the foundation of brick houses of worship consists of examples of late Baroque in the $18^{\text {th }}$ century. Inherited from the Orthodox church and administered by the Basilian monastery in Vilnius, the Orthodox Cathedral of the Theotokos, St. Parasceve Orthodox church and the main St. Trinity Orthodox Church were rebuilt in different periods. The Orthodox Cathedral of the Theotokos was no longer in use in the second half of the $18^{\text {th }}$ century. Nevertheless, the building was also reconstructed under Uniate rule and lost its early Gothic forms. Poor iconographic material shows that a pediment of restrained Baroque forms stood above the building. St. Parasceve Orthodox church could also have been reconstructed and acquired the features of Renaissance and Baroque architecture. The most striking Uniate features of late Baroque in the $18^{\text {th }}$ century were seen in St. Trinity former Orthodox church, which reflected the Baroque features of Vilnius. Until the reconstructions in the second half of $19^{\text {th }}$ century, a pediment and side towers designed by Johann Christoph Glaubitz were built above thee-part apses as well as side towers, built on the base of old Gothic corner towers. The elongated building took the form of the rectangular plan and lost the cubic structure close to the square plan typical for the early Orthodox churches. By reconstructing the building again into the Orthodox church in the second half of $19^{\text {th }}$ century, the building lost its more pronounced Baroque forms. Johann Christoph Glaubitz himself also worked on the installation of the monastery building and gates of the building. ${ }^{47}$ In the second half of the $18^{\text {th }}$ century, St. Nicholas' church became the pronounced vertical of Baroque architecture in the surroundings of Vilnius City Hall. After the city fires in the first half of the $18^{\text {th }}$ century, the Gothic style of the building acquired distinctive Baroque features. ${ }^{48}$ The architecture of the tower of this church was particularly close to the work of J. K. Glaubitz. The church itself functioned as a parish Uniate city church for a long time. The only striking old accents in the building were a combination of three apse at the back of the building. The building rising next to Didžioji Street was surrounded with buildings, therefore the architecture of the church in the general context of the city was first highlighted by looking at the tower of baroque forms typical of Vilnius Baroque architecture. The condition of this building is described by

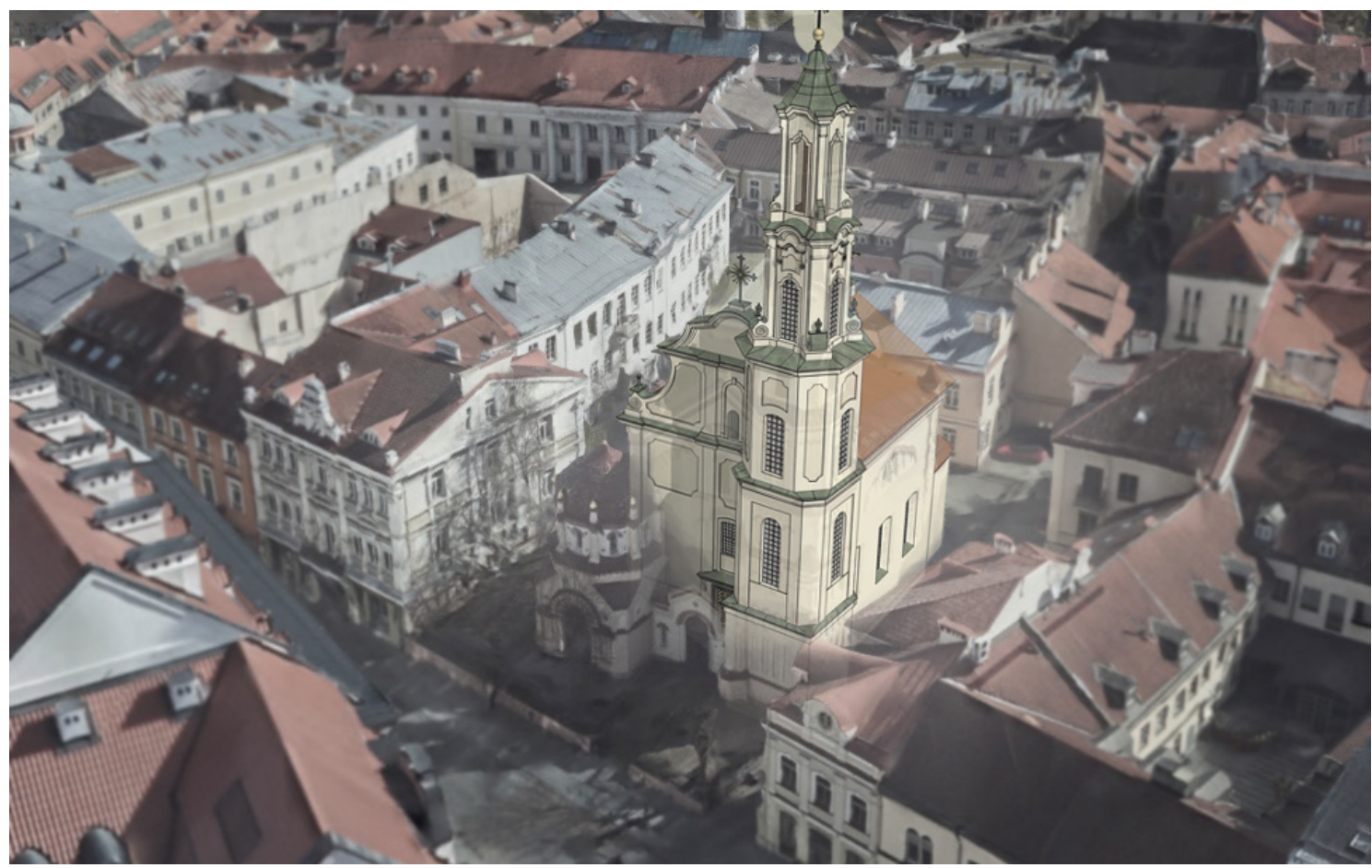

Fig. 4. Reconstruction of the Baroque image of Vilnius St. Nicholas Uniate parish church. Author of visual reconstruction: Žygimantas Buržinskas 


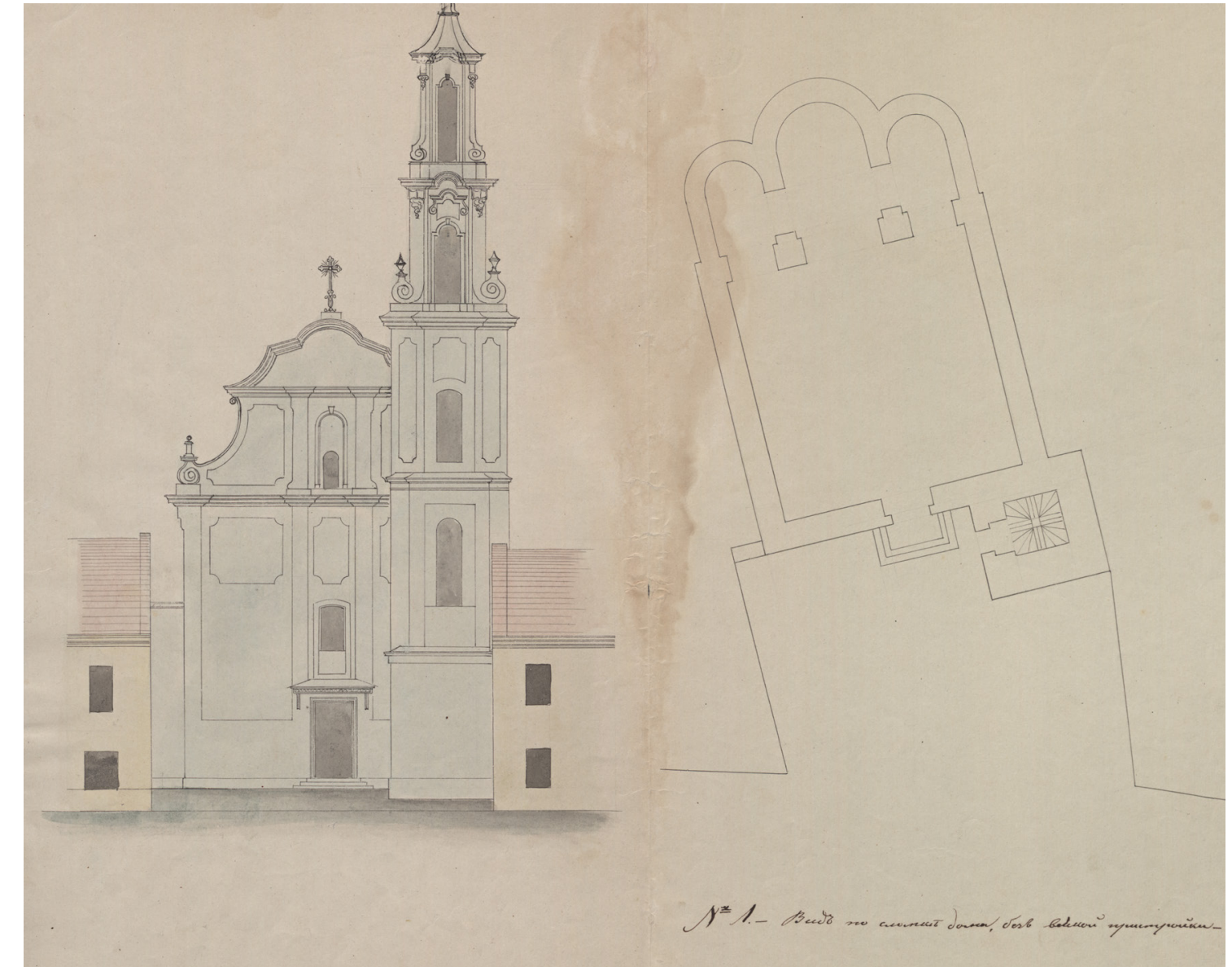

Fig. 5. Façade and plan drawings of the St. Nicholas Uniate parish church in Vilnius. First half of $19^{\text {th }}$ century. VUB RS F.78-244

drawings made by an unspecified author in the first half of the $19^{\text {th }}$ century. ${ }^{49}$

Like parish Unitarian Orthodox churches, many Basilian monastery churches started to be built or reconstructed in the $18^{\text {th }}$ century according to the examples of Catholic churches being built in the region. In this context, the Grodno Basilica Church, which was built before 1751, becomes a unique object, it has features of synthesis of Greek and Latin cross forms. During the transformation of the building into an Orthodox church, the axes of the formation of the sanctuary were swapped. Until then, the entrance was on the east side and the iconostasis was located next to the Western building, which was closed by an inner semi-circular apse. Above the transept is a dome with a regular circular drum. Allusions to the structure of the Greek plan are emphasised by the Baroque towers installed at the corners of the parts of the south-eastern axis of the Orthodox church..$^{50}$ The other Orthodox church of Kolozha in Grodno was built according to the old Orthodox traditions of Kievan Rus. ${ }^{51}$ In most cases, other buildings of Uniate church of the $18^{\text {th }}$ century can be attributed to the examples of Vilnius Baroque Catholic churches, in which two-tower, three-tiered basilica structure solutions were dominant. Peculiar interpretations of the structure of the Latin cross are also noticeable. The transept of the Berezvech Basilian Monastery Orthodox church built in 1756-1763 is more in the centre of the building's structure, behind the apse of which the basilica structure nave went further. ${ }^{52}$ St. Sophia Cathedral in Polotsk, reconstructed in 1738-1765, integrated parts of an old building destroyed during war in the beginning of the $18^{\text {th }}$ century. After changing the orientation of the building in the direction to the northsouth axis, the old apses of the building adapted to the function of the side chapel with a domed roof became apparent in the side façade. Due to the symmetry, a chapel was installed next to the side façade 


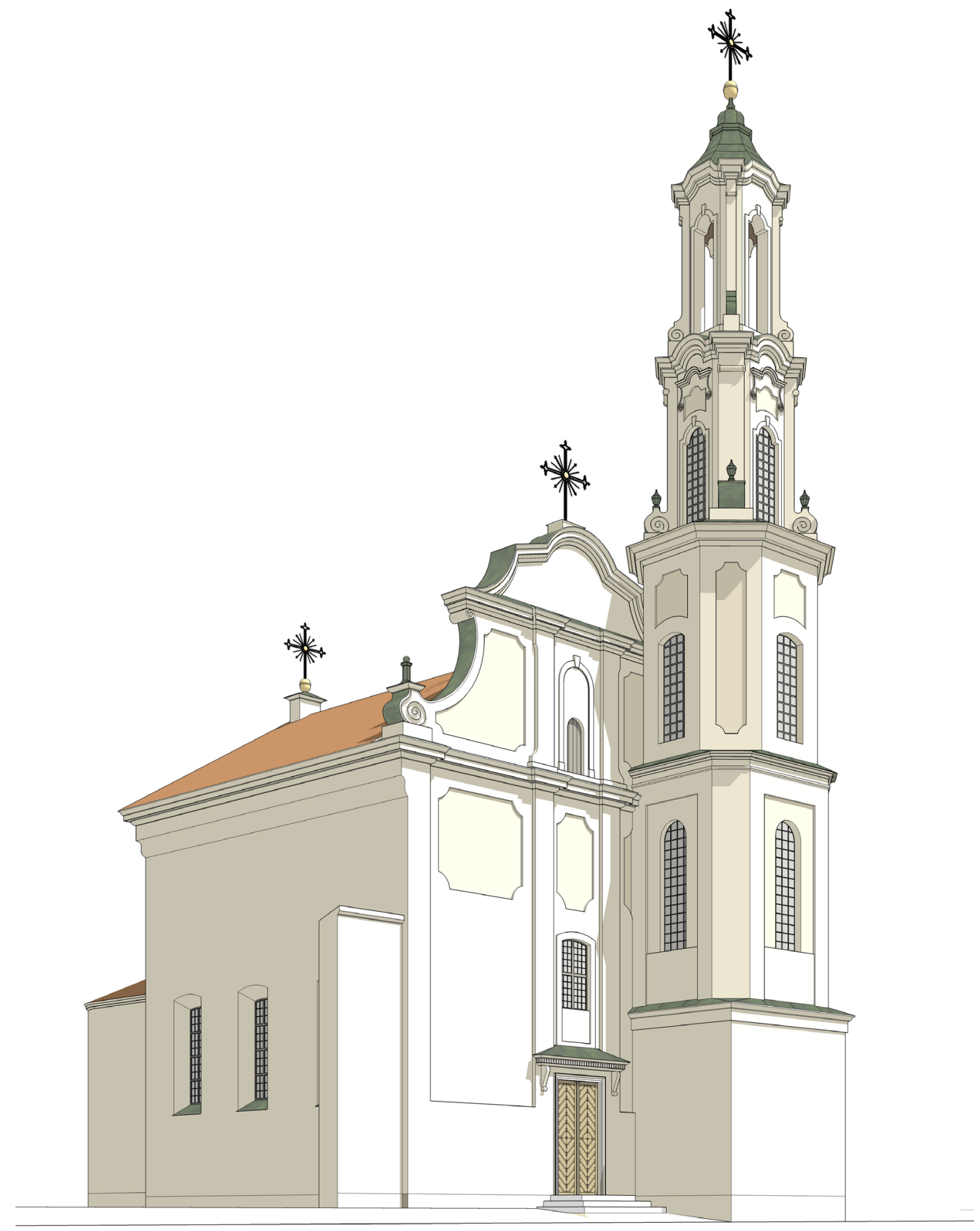

Fig. 6. Reconstruction of the Baroque image of Vilnius St. Nicholas Uniate parish church. Author of visual reconstruction: Žygimantas Buržinskas

of another building on the same principle. Vitebsk Men's Basilian Church acquired the standard structure of the three-nave basilica's Latin cross plan. ${ }^{53}$ The Orthodox church of St. Spirit that belonged to the Basilians of the same city, also had taken in the form of a smaller double-towered Latin cross with 
of Volna also has a Latin cross form and features of basilica structure. The transept of the building is separated from the towers only by one lane of bays. The presbytery of the building, which makes up more than a third of the length of the building, structurally incorporates the space of the transept in the central part of the building. The impression of the massiveness of the buildings is enhanced by the pediments attached to the towers of the building. The main church of the Zhyrovichy Monastery which underwent various reconstructions also makes a form of Latin cross three-nave basilica with dome. Nevertheless, in the original plan the building, built in the middle of the $17^{\text {th }}$ century, may have been close to the plan of the Greek cross. This is evidenced by the differences in the mass of the walls at the transept and the apse and the front part of the building. A planned structure of the two-tower system, which is close to other basilica buildings of this type, was formed during the Baroque period in the main façade part of the building. Basilica churches of Latin cross form with dome were also built in Orsha; the already mentioned Byten church also acquired such form after reconstruction. The iconographic material of the Leshche monastery in Pinsk testifies to the existence of this type of wooden church. ${ }^{55}$ A one-nave wooden Orthodox church of the Latin cross form, but without the towers, existed in the Liskava Basilian Monastery. ${ }^{56}$ Under the influence of late Baroque and Classicism forms, in the beginning of the $19^{\text {th }}$ century a brick church of Latin cross form with a dome was built in the Monastery of Pustinki. ${ }^{57}$ It is noteworthy that not all Uniate churches of Latin cross plan were built with domes rising above the roof of the church. The domes with the drums were replaced with internal vaulted domes integrated into the transept system. In the main church of Vitebsk's Basilians, a bright dome of regular circumference with a drum was installed only after the beginning on the $19^{\text {th }}$ century, when the reconstruction of the building was made after it was taken over by the Orthodox people. ${ }^{58}$
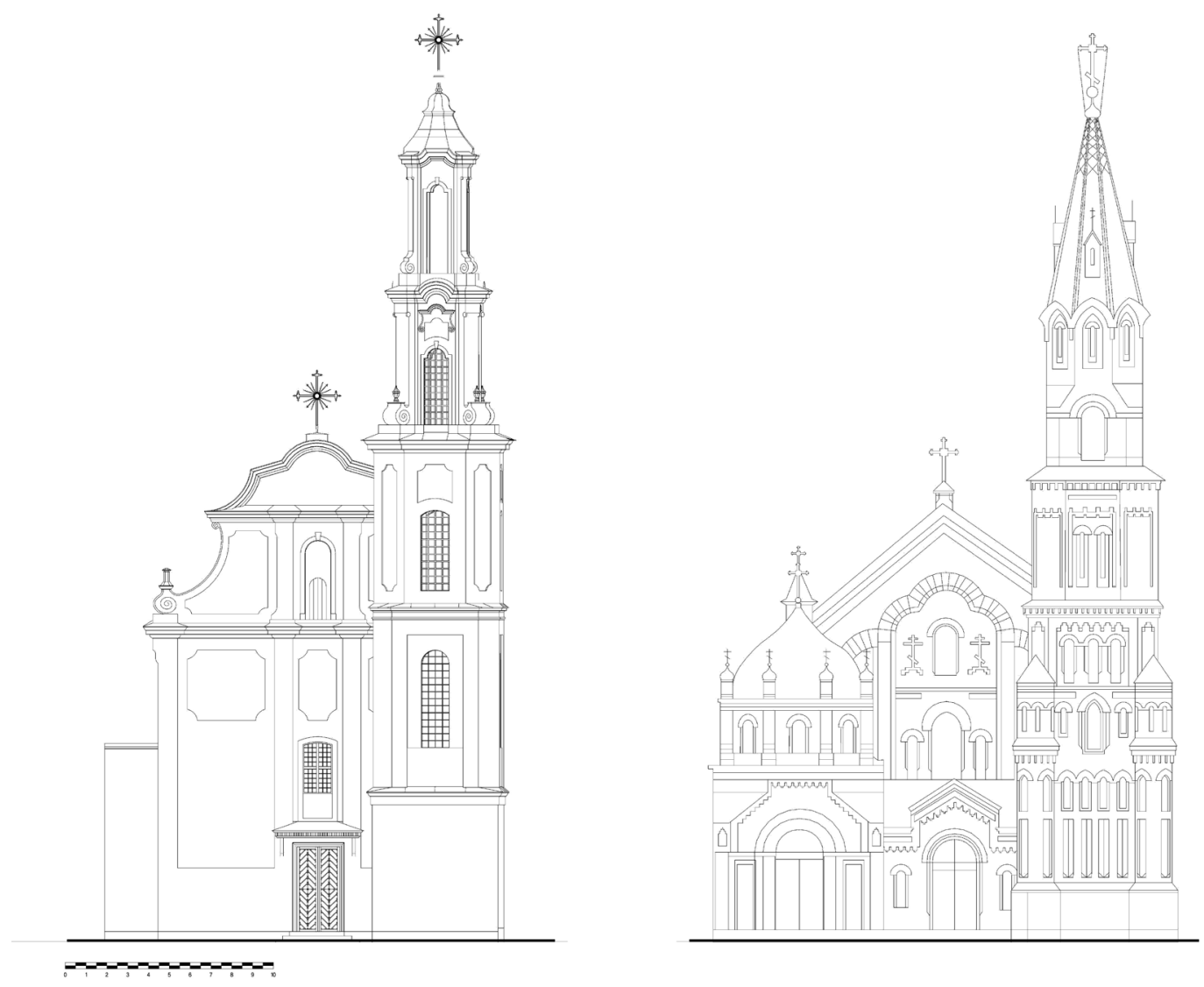

Fig. 7. Changes of the main façade of St. Nicholas Church after the reconstruction in the second half of the $19^{\text {th }}$ century. Prepared by Žygimantas Buržinskas 
A brick rectangular shaped basilica existed in BrestLitovsk, which was built in the second half of the $18^{\text {th }}$ century and had very close features to other Basilian and Catholic churches built at that time. The impression of the incompleteness of the building was formed by the system of two towers structurally formed in the front part, which was not finished, because the building did not have towers protruding above the towers of the main façade. ${ }^{59}$ Other Uniate churches of the basilica structure, built in the second half of the $18^{\text {th }}$ century existed in Tadulin, ${ }^{60}$ Talachyn, ${ }^{61}$ Tarakan (Imenin), ${ }^{62}$ Lyubavichi, ${ }^{63}$ and Baruny. Prominent among the basilicas was the Tarakan Basilian church, the side naves of which were arranged high enough that the clergy of the basilica structure had no windows. In addition to this type of church were single nave rectangular plan small volume church buildings in Lohoisk, ${ }^{64}$ Selets, ${ }^{65}$ Zhyrovichy, ${ }^{66}$ and Novy Svyerzhan. ${ }^{67}$ The apses of many Baroque churches were of semi-circular shape. The apse in the main Vitebsk Basilian church was formed originally in the context of the sacral buildings in the Grand Duchy of Lithuania. The lower side naves joined at the bottom of the apse, encircling the outside of the apse, maintaining the height of the naves as in the general basilica structure of the building. ${ }^{68}$ During the construction of Basilian churches in the second half of the $18^{\text {th }}$ century, their projects were prepared by the most famous Baroque architects of the Grand Duchy of Lithuania, who directly worked with sacral buildings of various denominations. Their architectural knowledge and design style were reflected in the architecture of various denominations, which in turn influenced the overall convergence of denominational architectural principles. Taken together, Uniate architectural tendencies leaned toward the architectural line of the Catholic church. In most cases, the buildings in the second half of the $18^{\text {th }}$ century differed little from the Catholic churches built both in the province and in the larger centres of the Grand Duchy of Lithuania. It is also noticeable that part of the Uniate buildings, which belonged to the Order of Basilians, in their mass and decoration did not give way to the construction of the Catholic churches. Individual cases marked even innovative

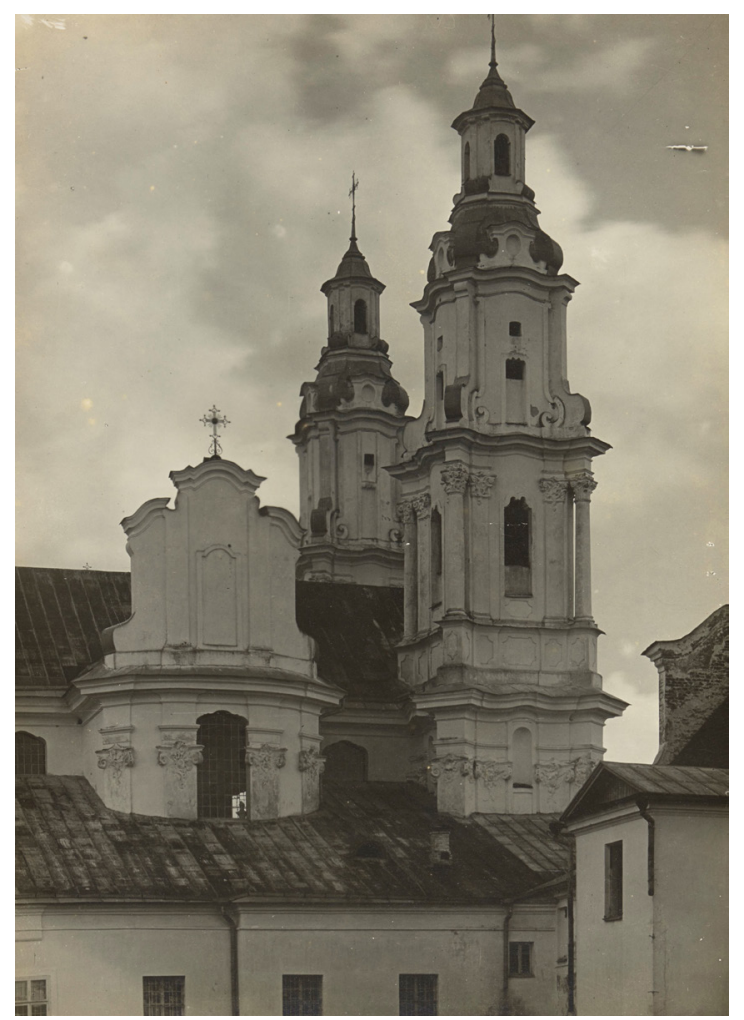

Fig. 8. Image of St. Peter and Paul the Apostles Basilian church in Berezvech before the World War II. Photo by Adam Wislocki. Narodowa Library, F.63136/II

and unique solutions in the entire architectural context of the Grand Duchy of Lithuania.

The network of brick parish churches in the territory of Grand Duchy of Lithuania was rather small; known examples of late brick churches are in Subote, ${ }^{69}$ Vitebsk, ${ }^{70}$ Velikaja Lipoje, ${ }^{71}$ Vishniaviec, ${ }^{72}$ Shchorsi ${ }^{73}$ and other areas. From an architectural point of view, the buildings were no longer built on the basis of original Orthodox building traditions but based on the prevailing examples of sacral architecture of Baroque and Classicism.

\section{CONCLUSIONS}

After the formation of Uniate Church organisation and the formation of the Order of Basilians after the Brest Union, most of the sacral buildings were taken over from Orthodox people, so the common architectural tradition was directly inherited from this denomination. Prior to the Union of Brest, an architectural tradition of the Orthodox church in the territory of the Grand Duchy of Lithuania was closely connected with the Gothic and Renaissance 
styles prevailing in the state, which also marked a feature of architectural synthesis in this denomination. From the very first buildings there is a noticeable spread of Renaissance and Baroque styles in the tradition of Uniate church, which was also widespread in the Catholic churches. In the architecture of the first sacral buildings of Uniates and Basilians, more elements of Orthodox architecture traditions widespread in the region of Central and South-Eastern Europe are noticeable. Most striking features can be observed in Krasnybór church, which has survived to this day but now Catholic-owned, and the destroyed Byten Church. The most striking features of the adoption of the Orthodox tradition were reflected in the Greek cross plans and the formation of semi-circular apses on different axes. In the other brick houses of worship, built in the first half of the $18^{\text {th }}$ century, the growing influence of the Catholic churches began to show, reflected in the one-nave building structure and towers built in the front part of the buildings.

Uniate wooden architecture sacral buildings, as well as first other sacral houses of worship ruled by this denomination, were taken from the Orthodox people, reflecting the shape of the buildings close to the square and quadrangular roof with a dome at the top. The structure of three part four-sloped roofs and domes at the top of the building, widespread in South-Eastern and Central Europe, was noticeable in the Uniate architecture. In addition to these buildings, the structure of the Latin and close to Greek cross plan of the buildings spread in the region, but a considerable part of the wooden buildings was built of one nave. Small volume domes of Baroque forms could have been formed in the middle part above the double-sloped roof. In the late Baroque period, wooden buildings of the basilica type also emerged among the wooden buildings, between which, as in the Catholic churches, towers were built at the front of the buildings. In addition to these elements, there were baroque decorative elements, curved façades and pediments taken from the architecture of Catholic churches. The general architecture of the newly built Uniate buildings in the second half of the 18th century no longer differed from the Catholic churches.

During the Late Baroque era, most of the sacral brick buildings were built in the Basilian monasteries. The number of constructions of brick parish churches was small, because a large part of the parish Orthodox churches was built in rural areas. The general architectural trend marked a significant influence on the construction of the Catholic Church, the general structure of the buildings and the architectural elements between the buildings under construction no longer differed substantially from other Baroque Catholic churches. Architectural convergence was also determined by the fact that architects who worked on buildings of various denominations were also involved in the construction of the buildings. The general architectural convergence was also determined by the tendencies of similarity of the liturgy of denominations, the direct contacts of the persons of the Unitarian Church organisation with the Catholic Church.

\section{References}

Brumfield, William Craft. A History of Russian Architecture. Seattle: University of Washington Press, 2004, 182.

Butvilaite, Rasa. "Vilniaus bazilijonų vienuolyno vartai". Vilniaus architektūros mokykla XVIII-XX a., Vilniaus dailess akademijos darbai 2. Vilnius: Vilniaus dailès akademija, 1993, 161-193.

Cerkiew po-unicka w Torokaniu. Z archiwum Instytutu Sztuki Polskiej Akademii Nauk. IS PAN 0000013988.

Drawings of façade and plans of St. Nicholas Orthodox Church, first half of $19^{\text {th }}$ century. VUB RS, F.78-244.

Inventory of Merkinè eldership 1695-1697 m. LVIA, f. 1541, ap. 1, b. 54 .

Jankauskas, Vidmantas. "Ką apie Gardino Koložos cerkvę pasakoja XIX a.-XX a. pr. ikonografija“. Dailès kūrinys - istorijos šaltinis. Sud. Skirmantė Smilingytè-Žeimienè. Vilnius: LKTI, 2016, 42-76.

Januszkewicz, Marcelli. Bazilijony vienuolynas Lahoisko pilyje. https://kolekcijos.biblioteka.vu.lt/islandora/ object/atmintis:VUB01_000366342.

Kantorowicz, Klara. "Architektura kolegiów jezuickich we Włoszech i w Rzeczypospolitej do połowy XVII wieku - poszukiwanie wzorów na wybranych przykładach“. Czasopismo Inżynierii Lądowej, Środowiska i Architektury, JCEEA, t. XXXIV, z. 64 (2/II/17), kwiecień-czerwiec 2017, s. 143-158. doi: $10.7862 / \mathrm{rb} .2017 .88$. 
Kołbuk, Witold. "Spór o konsekwencje Unii Bryeskiej w piśmiennictwie polskim i rosyjskim 1795-1915“. Colloquia Orientalia Bialostocensia 4 (2013): 167. https://repozytorium.uwb.edu.pl/jspui/bitstream/11320/8397/1/W_Kolbuk_Spor_o_konsekwencje_Unii_Brzeskiej.pdf.

Lorens, Beata. "Redukcja monasterów w prowincji koronnej Zakonu Ruskiego św. Bazylego Wielkiego w latach 1744-1780“. Hereditas Monasteriorum, vol. 8 (2016): 70-71.

Materiałów do dziejów sztuki sakralnej na ziemiach wschodnich dawnej Rzeczypospolitej, Kościoły i klasztory rzymskokatolickie dawnego województwa brzeskolitewskiego, cz. V, t. 3, Praca zbiorowa, Dorota Piramidowicz. Krokow: Międzynarodowe Centrum Kultury w Krakowie, 2016, 39.

Matus, Irena. "Obraz Cerkwi unickiej w obwodzie bialostockim na początku XIX wieku“. Studia wschodnioslowianskie, t. 15 (2015): 594.

Merkinè Magistrate's Book 1695-1737 m. LVIA, SA 5851, 1. 10.

Merkine manor land plan. First half of the $19^{\text {th }}$ century. LVIA, f. 526, ap. 7, b. 2103.

Orthodox church of David Gorodok before the World War II. IS PAN R0000026401

Ostrovskaja, Rūta. "Kruonio maldos namų konfesinès priklausomybès klausimas“. SOTER 41(69), 2012. https:// www.vdu.lt/cris/bitstream/20.500.12259/33254/1/ ISSN2335-8785_2012_N_41_69.PG_89-102.pdf.

Ostrovskaja, Rūta. "Unitai ir jų sakraliniai pastatai LDK". SOTER 16 (46) (2006): 137-152.

Ozheshkovskaya, Irina. "Basilian Order Monastic Temples Architecture on the Territory of Belarus in the 17th-First Half of the 19th Centuries". Advances in Social Science, Education and Humanities Research, vol. 324 (2019): 97-104.

Radwan, Marian. Bazylianie w zaborze rosyjskim w latach 1795-1839. 2000, 225. http://naszaprzeszlosc.pl/files/ tom093_06.pdf.

Remains of the Byten Basilian Monastery church. IS PAN 0000017297.

Ryżewski, Grzegorz. "Krasnoborskie klasztory“. Sztabin. Dzieje obszaru gminy Sztabin od czasów najdawniejszych do współczesności. Białystok-Sztabin, 2002, 77-79.

Sant'Ambrogio e Carlo al Corso Romoje bazilikinès bažnyčios pavyzdys. https://www.ldk-ticino.info/ss-ambroggio-e-carlo-al-corso.

Senyk, Sophia. "The Ukrainian Church and Latinization". Orientalia Christiana Periodica 56, no. 1 (1990): 174.

Temčinas, Sergejus. "Bažnytinès knygos rusenų kalba ir religiniai identitetai slaviškose Lietuvos Didžiosios Kunigaikštystės žemėse XIV-XVIII amžiuje: protestantų ir unitų tradicijos". Lietuvos istorijos studijos 28 (2011): 56.

Unici, PWN. Encyklopedia. Encyklopedia. pwn.pl/haslo/ unici;4010353.html.

Vaišvilaite, Irena. Pasivaikščiojimai po krikščioniškaji Vilnių. Vilnius: Baltos lankos, 2017, 274.

Wisłocki, Adam. Berezvéčiaus Apaštalų Šv. Petro ir Povilo bazilijonu cerkvés vaizdas iki II pasaulinio karo. Biblioteka Narodowa, F. 63136/II.
Архітэктура Беларусі. Энцыклапедычны даведнік. Мінск: Беларуская Энцыклапедыя імя Петруся Броўкі, 1993.

Акты Виленской археографической комиссии: Том XI. Акты Главного титовского трибунала. Вильна: издательство А. К. Киркора, 1880, 273. https://runivers.ru/lib/book3036/9555/.

Вітэбская энціклопедыя, Свято-Духовская церковь. evitebsk.com/wiki/Свято-Духовская_церковь.

Габрусь, Тамара. Мураваныя хараль: сакральная архітэктура беларускага барока. Мінск: Ураджай, 2001, 183.

Графічная рэканструкцыя царквы Святых Пятра і Паўла кляштару базыліянаў. Незакончаны выгляд на пачатак XIX ст. 3D мадэль, арыгінальныя фота, фотамантаж А. Nevar, 2019. http://history-belarus. by/pages/arch_brest/brest_brestPeterPavel.php.

Графічнае адраджэньне страчанай архітэктурнай спадчыны. http://history-belarus.by/pages/arch_ about/aboutProject.php?fbclid=IwAR0zTQvHNGjmaBCnS0jvMi9jayleBFMp_R6ZlXMoXW1RRitervaoo3h8yy0.

Збор помнікаў гісторыі $і$ культуры Беларусі. Віцебская вобласць. Мінск: Беларуская Савецкая Энцыклапедыя імя Петруся Броўкі, 1985, 444.

Збор помнікаў гісторыі $i$ культуры Беларусі. Гродзенская вобласць. Мінск, Беларуская Савецкая Энцыклапедыя імя Петруся Броўкі, 1986, 280.

Збор помнікаў гісторыі $і$ культуры Беларусі. Магілёуская вобласць. Мінск: Беларуская Савецкая Энцыклапедыя імя Петруся Броўкі, 1986, 316.

Збор помнікаў гісторыі і культуры Беларусі. Мінская вобласиъ. Кніга 2. Мінск: Беларуская Савецкая Энцыклапедыя імя Петруся Броўкі, 1987, 111.

Кушнярэвіч, Аляксандр Мікалаевіч. Культавае дойлідства Беларусі XIII-XVI cm. Мінск: Навука i тэхніка, 1993, 21.

Лысково (Брестская область, Пружанский район). https://orda.of.by/.add/showimage.php?image=../. ga/l/lyskovo/index/sf/.big/232a.jpg.

Любавічы. Царква Успення Прасвятой Багародзіцы - фотаздымкі. https://radzima.org/be/objectphoto/4442.html.

Рэлігія $і$ царква на Беларусі. Энцыклапедычны даведнік. Минск: Беларуская Энцыклапедыя імя Петруся Броўкі, 2001, 355.

Свод памятников истории и культуры Белоруссии. Брестская область. Минск: Белорусская Советская Энциклопедия имени Петруся Бровки, 1990, 305.

Слепцов, Олег. Архитектура Православного Храма. От замысла к воплощению. Киев: А+C, 2012, 60.

Слюнькова, Инесса. Монастыри восточной и западной традиций. Наследие архитектурь Беларуси. Москва: Прогресс-Традиция, 2002.

Страчаная спадчына. Уклад. Т. В. Габрусь. Мінсk: Беларусь, 2003.

Тадулін (Слабада, Віцебскага раёна). Графічная рэканструкцыя Успенскай царквы былога базыліянскага манастыра (пазней праваслаўнага). 3D мадэль - A. Невар. 2017. http://history-belarus. by/pages/arch_vitebsk/vitebsk_tadulin.php. 
1 This was greatly influenced by the Synod of Zamosc that took place in 1720 and which paved the way for the formation of the liturgy in the Catholic direction. In: Sophia Senyk, "The Ukrainian Church and Latinization", Orientalia Christiana Periodica vol. 56, no 1 (1990), 174.

2 From the $18^{\text {th }}$ century acts of visits of Unitarian parishes were drafted in Polish, sometimes Latin languages. Looking at the Western areas of Unitarian territories, the ecclesiastical old Slavic language became poorly possible, with cases when there were no readers of Cyrillic alphabet. In: Irena Matus, "Obraz Cerkwi unickiej w obwodzie bialostockim na początku XIX wieku“, Studia wschodnioslowianskie, t. 15, 2015, 594; Sergejus Temčinas, "Bažnytinès knygos rusènų kalba ir religiniai identitetai slaviškose Lietuvos Didžiosios Kunigaikštystės žemėse XIV-XVIII amžiuje: protestantų ir unitų tradicijos", Lietuvos istorijos studijos 28 (2011), 56.

3 Witold Kołbuk, "Spór o konsekwencje Unii Bryeskiej w piśmiennictwie polskim i rosyjskim 1795-1915“, Colloquia Orientalia Bialostocensia 4 (2013), 167, looked at in 17 April, 2021, https://repozytorium.uwb.edu.pl/jspui/ bitstream/11320/8397/1/W_Kolbuk_Spor_o_konsekwencje_Unii_Brzeskiej.pdf.

4 In 1772 there were about 9650 parishes, which accounted for almost twice the number of parishes in the Catholic church. In the end of $18^{\text {th }}$ century, over 4.5 million Unitarians lived in the Republic of Two Nations, most of which were peasants. In: "unicy", $P W N$, looked at in 17 April, 2021, encyklopedia.pwn.pl/haslo/unici; 4010353. html.

5 Marian Radwan, Bazylianie $w$ zaborze rosyjskim $w$ latach 1795-1839 (2000), 225, looked at in 17 April, 2021, http://naszaprzeszlosc.pl/files/tom093_06.pdf.

6 Beata Lorens, "Redukcja monasterów w prowincji koronnej Zakonu Ruskiego św. Bazylego Wielkiego w latach 1744-1780", Hereditas Monasteriorum, vol. 8 (2016), 70-71.

7 Rūta Sotrovskaja, "Kruonio maldos namų konfesinès priklausomybės klausimas", SOTER 41(69) (2012), looked at in 17 April, 2021, https://www.vdu. $\mathrm{lt} / \mathrm{cris} / \mathrm{bitstream} / 20.500 .12259 / 33254 / 1 /$ ISSN23358785_2012_N_41_69.PG_89-102.pdf.

8 Rūta Janonienè, "Architektūrinis ansamblis", Kultūru kryžkelè. Vilniaus Švč. Trejybès šventove ir vienuolynas, collective monograph (Vilnius: Vilniaus universiteto leidykla, 2017), 211-224.

9 Rasa Butvilaite, "Vilniaus bazilijonų vienuolyno vartai, Vilniaus architektūros mokykla XVIII-XX a.", Vilniaus dailes akademijos darbai 2 (Vilnius: Vilniaus dailès akademija, 1993), 161-193.

10 Rūta Ostrovskaja, "Unitai ir jų sakraliniai pastatai LDK“, SOTER 16 (46) (2006), 137-152.

11 Grzegorz Ryżewski, "Krasnoborskie klasztory”, Sztabin. Dzieje obszaru gminy Sztabin od czasów najdawniejszych do wspótczesności (Białystok-Sztabin, 2002), 77-79.

12 Рэлігія $і$ изарква на Беларусі. Энцыклапедычны даведнік (Минск: Беларуская Энцыклапедыя імя Петруся Броўкі, 2001); Збор помнікаў гісторы $i$ культуры Беларусі. Віцебская вобласцьь (Мінск: Беларуская Савецкая Энцыклапедыя імя Петруся Броўкі, 1985), 29; Збор помнікаў гісторыі і культуры Беларусі. Гродзенская вобласць (Мінск: Беларуская
Савецкая Энцыклапедыя імя Петруся Броўкі, 1986); Збор помнікаў гісторыі і культуры Беларусі. Магілёуская вобласиь (Мінск: Беларуская Савецкая Энцыклапедыя імя Петруся Броўкі, 1986); Свод памятников истории и культуры Белоруссии. Брестская область (Минск: Белорусская Советская Энциклопедия имени Петруся Бровки, 1990).

13 Страчаная спадчына, Уклад. Т. В. Габрусь (Miнck: Беларусь, 2003); Тамара Габрусь, Мураваныя харалы: сакральная архітэктура беларускага барока (Мінск: Ураджай, 2001).

14 Инесса Слюнькова, Монастыри восточной и западной традиций. Наследие архитектуры Беларуси (Москва: Прогресс-Традиция, 2002).

15 Irina Ozheshkovskaya, "Basilian Order Monastic Temples Architecture on the Territory of Belarus in the $17^{\text {th }}$-First Half of the $19^{\text {th }}$ Centuries", Advances in Social Science, Education and Humanities Research, vol. 324 (2019), 97-104, https://doi.org/10.2991/ahti-19.2019.21.

16 Графічнае адраджэньне страчанай архітэктурнай спадчыны, looked at in 17 April, 2021, http://history-belarus.by/pages/arch_about/aboutProject. php?fbclid=IwAR0zTQvHNGjmaBCnS0jvMi9jayleBFMp_R6ZlXMoXW1RRitervaoo3h8yy0.

17 Drawings of façade and plans of St. Nicholas Orthodox Church, first half of $19^{\text {th }}$ century, VUB RS, F. 78-244.

18 Merkine manor land plan. First half of the 19th century, LVIA, f. 526, ap. 7, b. 2103.

19 Merkine Magistrate's Book 1695-1737 m., LVIA, SA 5851, 1. 10.

20 Inventory of Merkinè eldership 1695-1697 m., LVIA, f. 1541, ap. 1, b. 54 .

21 Krasnybór, Podlaskie Voivodeship, present-day Poland.

22 There has been a well-established statement in historiography that the Kruonis Church belonged to the Basilians, but there is no basis for such statements. In: Rūta Ostrovskaja, "Kruonio maldos namų konfesinès priklausomybès klausimas", SOTER 41(69) (2012), 89-102, looked at in 17 April, 2021, https://www.vdu. lt/cris/bitstream/20.500.12259/33254/1/ISSN23358785_2012_N_41_69.PG_89-102.pdf

23 Grzegorz Ryżewski, “Krasnoborskie klasztory”, Sztabin. Dzieje obszaru gminy Sztabin od czasów najdawniejszych do współczesności (Białystok-Sztabin, 2002), 79.

24 Ibid., 77.

25 A close example of this type was discovered in the house of prayer built in Polotsk in $12^{\text {th }}$ century, but the building was shaped of a rectangular plan without a more pronounced transept. In: Аляксандр Мікалаевіч Кушнярэвіч, Культавае дойлідства Беларусі ХІІІ-XVI ст (Мінск: Навука і тэхніка, 1993), 21.

26 William Craft Brumfield, A History of Russian Architecture (Seattle: University of Washington Press, 2004), 182.

27 In this regard, the former St. Trinity and St. Elijah the Propjet Orthodox Churches in Vitebsk, Mscislav St. Spirit Church, the apses of which were formed in the triangular principle.

28 Олег Слепцов, Архитектура Православного Храма. От замысла к воплощению (Киев: А+С, 2012), 60.

29 Links with the Caucasus region are strengthened by the discoveries of the remains of a house of prayer of $12^{\text {th }}$ 
century in Polotsk, the planned structure of which is close to the Bagrati Orthodox Church built in $11^{\text {th }}$ century in Kutaisi (Sakartvel).

30 In present-day Ukraine there are surviving churches in Sutkovci, Adamkova, Podolsk Kamenets, Pusiatin, Ternopil, Sharovka and others, which have the features of defensive functions.

31 Страчаная спадчына, Уклад. Т. В. Габрусь (Miнck: Беларусь, 2003), 141.

32 Ibid., 142.

33 The location is near the town of Cherea (Черея), in the present-day Vitebsk region.

34 Инесса Слюнькова, Монастыри восточной и западной традиций. Наследие архитектуры Беларуси (Москва: Прогресс-Традиция, 2002), 58.

35 In the Publication Рэлігія $і$ изарква на Беларусі it is stated that the building was built in 1599. In: Рэлігія $i$ царква на Беларусі. Энцыклапедычны даведнік (Минск: Беларуская Энцыклапедыя імя Петруся Броўкі, 2001), 355; In the Publication 3бор помнікау гісторы і і культуры. Віцебская вобласиь it is stated that the Orthodox church building was rebuilt in 17th century. In: Збор помнікаў гісторьі і культуры Беларусі. Віцебская вобласиь (Мінск: Беларуская Савецкая Энцыклапедыя імя Петруся Броўкі, 1985), 444.

36 Инесса Слюнькова, Монастыри восточной и западной традиций. Наследие архитектуры Беларуси (Москва: Прогресс-Традиция, 2002), 57.

37 Also called Bazilijonai, present-day district of Šiauliai. 38 After the partitions of the Polish-Lithuanian Commonwealth in current Lithuanian territory, in 1810 a new small brick Uniate church was built in Vilūnai village. 39 Kalubiškès folwark was located about 6 kilometers Southeast of Merkine nar the Merkys River.

40 Акты Виленской археографической комиссии: Том XI. Акты Главного литовского трибунала (Вильна: издательство: А. К. Киркора, 1880), 273, looked at in 20 April, 2021. https://runivers.ru/lib/book3036/9555/.

41 The will of the Unitarian citizen, 1695, states that he wants to be buried next to the church. The church priest is also mentioned. In: Merkine Magistrate's Book 16951737 m., LVIA, SA 5851, 1. 10.

42 Merkine manor plan, LVIA, f. 526, ap. 7, b. 2103.

43 Дивин.

44 Chotislav, Brest County. The church was built in 1799.

In: Свод памятников истории $и$ культуры Белоруссии. Брестская область. Минск: Белорусская Советская Энциклопедия имени Петруся Бровки, 1990), 305.

45 Opalio, Diadovich, Orthodox church, Brest County. Orthodox church built in the second half of $18^{\text {th }}$ century. In: Ibid., 197.

46 Materiałów do dziejów sztuki sakralnej na ziemiach wschodnich dawnej Rzeczypospolitej, Kościoły i klasztory rzymskokatolickie dawnego województwa brzeskolitewskiego, cz. V, t. 3, Praca zbiorowa, Dorota Piramidowicz (Krokow, Międzynarodowe Centrum Kultury w Krakowie, 2016), 39.

47 Rasa Butvilaite, "Vilniaus bazilijonų vienuolyno vartai“, Vilniaus architektūros mokykla XVIII-XX a., Acta Academiae Artium Vilnensis / Vilniaus dailes akademijos darbai 2 (Vilnius, 1993), 161-193.

48 Irena Vaišvilaitè, Pasivaikščiojimai po krikščioniškaji Vilniu (Vilnius: Baltos lankos, 2017), 274.
49 Šv. Mikalojaus cerkvès Vilniuje fasado ir plano brèžiniai, XIX a. I puse, VUB RS, F. 78-244.

50 Тамара Габрусь, Мураваныя харалы: сакральная архітэктура беларускага барока (Мінск, Ураджай, 2001), 190-191.

51 Vidmantas Jankauskas, "Ką apie Gardino Koložos cerkvę pasakoja XIX a.-XX a. pr. ikonografija“, Dailès kūrinys - istorijos šaltinis (Vilnius: LKTI, 2016), 42-76.

52 This kind of transept formation also occurred among the Jesuit churches: In: Klara Kantorowicz, "Architektura kolegiów jezuickich we Włoszech i w Rzeczypospolitej do połowy XVII wieku - poszukiwanie wzorów na wybranych przykładach, Czasopismo Inżynierii Lądowej, Środowiska i Architektury“, JCEEA, t. XXXIV, z. 64 (2/ II/17), kwiecień-czerwiec 2017, s. 143-158, doi: 10.7862/ rb.2017.88.

53 Тамара Габрусь, Мураваныя хараль: сакральная архітэктура беларускага барока, 184-185.

54 Свято-Духовская церковь, Вітэбская энціклопедыя, žiūrèta $2021 \mathrm{~m}$. gegužès 3 d., evitebsk. com/wiki/Свято-Духовская_церковь.

55 Рэлігія $і$ иарква на Беларусі. Энцыклапедычны даведнік (Минск: Беларуская Энцыклапедыя імя Петруся Броўкі, 2001), 250.

56 Photo of Liskava Basilian Monastery Churhc, looked at in 3 May, 2021, https://orda.of.by/.add/showimage. php?image =../.ga/l/lyskovo/index/sf/.big/232a.jpg.

57 Збор помнікаў гісторы $і$ культуры Беларусі. Магілёуская вобласиь (Мінск: Беларуская Савецкая Энцыклапедыя імя Петруся Броўкі, 1986), 316.

58 Тамара Габрусь, Мураваныя хараль: сакральная архітэктура беларускага барока, 184-185.

59 Графічная рэканструкцыя царквы Святых Пятра і Паўла кляштару базыліянаў. Незакончаны выгляд на пачатак XIX ст. 3D мадэль, арыгінальныя фота, фотамантаж A. Nevar, 2019, looked at in 3 April, 2021, http://history-belarus.by/pages/arch_brest/brest_brestPeterPavel.php.

60 Тадулін (Слабада, Віцебскага раёна) Графічная рэканструкцыя Успенскай царквы былога базыліянскага манастыра (пазней праваслаўнага). 3D мадэль - А. Невар. 2017, looked at on 3 April, 2021, http://history-belarus.by/pages/arch_vitebsk/vitebsk_ tadulin.php.

61 Архітэктура Беларусі. Энцыклапедычны даведнік (Мінск: Беларуская Энцыклапедыя імя Петруся Броўкі, 1993), 467.

62 Cerkiew po-unicka w Torokaniu. Z archiwum Instytutu Sztuki Polskiej Akademii Nauk, IS PAN 0000013988.

63 Любавічы. Царква Успення Прасвятой Багародзіцы - фотаздымкі, looked at in 4 April, 2021, https://radzima.org/be/object-photo/4442.html.

64 Marcelli Januszewicz, Bazilijony vienuolynas Lahoisko pilyje (1850), looked at in 4 April, 2021, https://kolekcijos.biblioteka.vu.lt/islandora/object/ atmintis:VUB01_000366342.

65 Архітэктура Беларусі. Энцыклапедычны даведнік, 52.

66 Ibid., 215.

67 Тамара Габрусь, Мураваныя хараль: сакральная архітэктура беларускага барока, 72-73.

68 Sant'Ambrogio e Carlo al Corso Romoje bazilikinès bažnyčios pavyzdys, looked at in 7 April, 2021, https:// www.ldk-ticino.info/ss-ambroggio-e-carlo-al-corso. 
69 Subote, present-day Brest County. The Orthodox church was built in the end of $18^{\text {th }}$ century.

70 The Orthodox curch of Resurrection, built next to the market square, was consecrated in 1772. In: Tамара Габрусь, Мураваныя хараль: сакральная архітэктура беларускага барока (Мінск: Ураджай, 2001), 183.

71 Church built in the end of $18^{\text {th }}$ century. In: $360 p$ помнікаў гісторыі $і$ культуры Беларусі. Мінская вобласиьь. Кніга 2, (Мінск: Беларуская Савецкая Энцыклапедыя імя Петруся Броўкі, 1987), 111.

72 Ibid., 236.

73 Built in 1776. In: Збор помнікаў гісторы і і культуры Беларусі. Гродзенская вобласиь (Мінск: Беларуская Савецкая Энцыклапедыя імя Петруся Броўкі, 1986), 280.

\section{Žygimantas BURŽINSKAS}

Vytauto Didžiojo universitetas, Kaunas, Lietuva

\section{UNITU SAKRALINĖ ARCHITEKTŪRA LIETUVOS DIDŽIOJOJE KUNIGAIKŠTYSTĖJE: KONFESIJŲ ARCHITEKTŪROS SINTEZE்}

\section{Santrauka}

Unitų architektūrinis palikimas buvusioje Lietuvos Didžiojoje Kunigaikštystėje iki šių dienų yra sulaukęs tik nedidelio tyrèjų dèmesio. Šiame straipsnyje pristatoma unitu ir bazilijonų ordino architektūrinè sintezè, kuri atspindèjo senajj̨ stačiatikių architektūros paveldo perimamumą, bet kartu vis labiau buvo ịtakota katalikų bažnyčiose suformuotos architektūrinès tradicijos. Šiame straipsnyje pristatomos unitų architektūros raidos tendencijos, kreipiamas dèmesys ị Lietuvos Didžiosios Kunigaikštystès teritorijoje buvusius unitų ir bazilijonų ordinui priklausiusius mūrinius bei medinès architektūros sakralinius pastatus. Ankstyvieji unitų sakraliniai pavyzdžiai atspindèjo vis dar ryškius sintezės bruožus, kurie ypač pasižymėjo graikiško kryžminio plano ir apsidžių skirtingose pastatų ašyse formavime. Visa tai žymëjo Ukrainos, Moldovos ir kitų Vidurio, Pietryčiu Europos regiono teritorijų architektūrines įtakas, kurios buvo ryškiai pastebimos ir stačiatikių architektūroje. Medinẻ unitų architektūra, kaip ir mūro pastatų atveju, pirminiais bruožais turẻjo ryškius paveldètus stačiatikių architektūros bruožus, o velyvesniuoju periodu, dar XVIII a., pastebimos katalikų bažnyčiu architektūros principų perèmimo tendencijos, kurios lèmè didesnès dalies unitų pastatų visišką suartėjimą su katalikų bažnyčių pastatų pavyzdžiais. Vẻlyvojo baroko epochoje atsiradusi Vilniaus baroko mokykla suformavo bendras unitų ir katalikų sakralinių pastatų statybos tendencijas, tarp kurių jau XVIII a. II pusèje didesnių struktūrinių, meninių principų ryškesnès takoskyros jau nepastebima. Straipsnyje taip pat pristatomas XIX a. II puseje rekonstruotos vienintelès tuo metu Vilniaus miesto parapijinės unitų baroko epochos Šv. Mikalojaus cerkves vaizdinys.

Reikšminiai žodžiai: unitai, vaizdinio rekonstrukcija, katalikų bažnyčia, stačiatikių cerkvè, bazilijonų vienuolynai.

\section{Žygimantas BURŽINSKAS}

PhD candidate at the Faculty of Arts, Vytautas Magnus University, Kaunas, Lithuania Address: Muitinès g. 7, LT-44280, Kaunas, Lithuania

E-mail: zygimantas.burzinskas@vdu.lt 